\title{
Self-Assessment and Moral Righteousness
}

\author{
Laurence Thomas* \\ Political Science and Philosophy, Syracuse University, USA
}

Submission: : December 15, 2018; Published: December 20, 2018

*Corresponding author: Laurence Thomas, Political Science and Philosophy, Syracuse University, USA

\section{Perspective}

An indisputable truth is that there are many aspects to living well. Eating well and engaging in an enough exercise are two factors that come readily to mind as to ways of behaving that mightily contribute to living morally well. Notwithstanding the indisputable importance of these two factors, it is manifestly obvious, however, that not all have the wherewithal to live morally well. There are two factors that are necessary for living morally well:

a. Having and exhibiting the capacity for substantive, and thus correct, self-assessment.

b. Exhibiting upright behavior to a considerable degree regardless of the social context. Starting with $b$, the idea is not that a person should have as an aim to impose herself or himself upon others. Rather, the idea is that unless an observer is lacking in adequate understanding about what counts as upright behavior, then she or he should have little, if any difficulty in recognize an instance of such behavior on the part of an individual who is so behaving. And quite frankly the lack of adequate understanding should be quite rare by the time a person has become a 21-year old adult.

A simple example is useful here. If an 18-year old sees fall to the ground a somewhat older adult who is 15 feet away, it should spontaneously occur to the 18-year old to get help for the person who has fallen. Only if the 18 yea- old person has ample medical training should the young person assume that she or he has enough training to indeed help the individual in need. The idea of the preceding paragraph applies mutandis mutatis to living a morally upright life. Some individuals have the wherewithal to do the right thing (and thus resist the temptation to do otherwise) no matter where they might be and what might be going on around them. Alas, there are many individuals who are not so configured psychologically and emotionally. In other words, it is very rare that an individual either:

a. Does not realize that she or he has a substantial measure of strength of character or

b. Does not realize that she or he lacks a substantial measure of strength of character.
Various individuals may pay lip-service to the idea that they have strength of character. But needless an ever so clear indication that a person is mistaken in that regard is none other than the fact that although the person is clearly quite healthy, the individual nonetheless wallows in the idea that she or he has an acceptable excuse for not offering help to someone whom she or he sees to be clearly in need of assistance.

A non-trivial truth is that the self-assessment that a human being makes of herself or himself can indeed, be an ever so clear indication of the individual's moral righteousness provided that the self-assessment majestically and mightily underwrites the proclivity and importance of providing assistance to a perfect stranger in need, given that there is no respect at all in which by doing so the person providing the assistance would thereby harm herself or himself to a considerable degree or even end up dead. It goes without saying that there are individuals who quite willing to sacrifice their life in order to save the life of another. Such individuals are typically socials or police officers. Soldiers tend an ever so clear case in point. Indeed, ap tremendous lips service to this or that example of appropriate behavior. But when they are ever so tempted to get away with performing the available inappropriate behavior without anyone knowing about it, then it clearly follows that they are lacking in strength of character. re in effect psychologically driven to do so. For one of the defining features of being a morally upright person is that of having the wherewithal to do the right thing temptations to the contrary notwithstanding.

To be sure, the ideal is that of persons not at all having the temptation to do that which is inappropriate. Just so, there is clearly a straightforward sense in which an individual surely does what is admirable if the individual does the right thing even though the individual unequivocally experiences the temptation to do otherwise. Such an individual exhibits the self-command of doing the right thing notwithstanding the temptation not do so. And that is an ever so majestic form of moral excellence. For having

a. The wherewithal to do the right thing notwithstanding

b. The temptation to do otherwise 
c. Constitutes having considerable strength of character. And that is a most significant moral benefit. Alas, the reality is that it turns out often enough that an individual think that she or he has enough strength of character when such is not the case. An individual who recognizes that such is the case can either wallow in being ashamed of herself or himself. Or the individual can turn to bringing it about that indeed she or he comes to have considerable strength of character.

What is more important: (i) a person wallowing in the fact that she or he does not measure up or (ii) a person immediately moving to measure up upon having realized that she or he has not yet done so. It strikes me as manifestly obvious that (ii) is the choice to make, since merely wallowing in such a case is not at all beneficial. In general, it is far more important to help a person advance, then it is to criticize a person for having not yet advanced. To be sure, a person can be open to serious criticism for not having already advanced. However, a question that immediately presents it is the following: Which would be more beneficial: (a) criticizing a person for not having already measured up or (b) embracing and expressing in the fact that individual is now doing so? As no doubt one imagines, the answer depends on what will be accomplished. We all know that there most certainly can be cases in which criticizing a person occasions a very beneficial outcome. But we also know that there can be cases where criticizing a person can do more than good.

The wherewithal to resist a substantial temptation to do what is inappropriate is properly characterized as having tremendous strength of character. It goes without saying that the ideal would be to be without any temptation whatsoever to do that which wrong. In a world of righteous angles that ideal would surely be a majestic moral gift. But in a world of human beings, having or witnessing temptations upon occasion may be ever so efficacious in motivating individuals to behave properly. For in bearing witness to the temptation, the individual is thereby witnessing precisely she or he should not do. To be sure, a person should not need to be reminded not to perform utterly horrific behavior. But it is a reality that there can be instances of wrongful behavior that do not stand as morally horrific behavior. Suppose that a $\$ 20$ bill dropped out of a person's pocket as the individual was running across the street. It goes without saying that the ideal would be to get the $\$ 20$ bill back to the person. But there can be instances where doing so requires so much effort that it is excuses the person who picked up the $\$ 20$ but who did not try to get it back to the individual (now 2 blocks away) out of whose pocket the $\$ 20$ bill fell. who dropped it. s out of a person's pocket. And a part of being upright consists in having the wherewithal to resist performing behavior of that sort. Alas, unless there is a transformation which results in the person utterly hating to perform the wrongful behavior in question, there is clearly something to be said for some individuals being reminded of the utter inappropriateness of the behavior. There is no denying the reality that there are tremendously righteous individuals who do not at all need to be reminded of what counts as appropriate behavior. training to save an activity that will occasion some assistance to the person who has fallen. The odds are that for most 21-year old individuals, the only plausible activity which they can perform is that of either calling for an ambulance or calling the police. Just so, either choice is clearly better than no activity at all. By contrast, if a 32-year old physician who has walked out the grocery store quite clearly sees that there is something substantive that she can do to help the fallen person, then it is manifestly clear that physician should so behave.

A most fascinating fact about human beings when they are at their very best is that they are ever so likely to have clear sense of the options available to them when it is ever so evident that to them someone needs assistance. Indeed, I should like to suggest that one respect in which a just society is clearly at its best is none other than the reality that a great many members of that society have that insight with respect to themselves. The idea here is that while many members of a society no doubt have a way of living that other human beings value, it is also the case that there are sufficiently many members of society who have a moral objectivity that transcends to a considerable degree the way in which the average citizen randomly chosen is prepared to act given the clear observation that someone is considerably suffering. sufficiently many members of society who have the strength of character to put their very life on the line in order to be of help to a person in the throughs of suffering.

In effect, the ever so deep point here is that it is not possible to truly be a morally decent and helpful person in the absence of enough self-knowledge. Quite surprisingly no doubt, knowing that one is, indeed, in the position to help a person who needs assistance is rather parallel to correctly knowing that one can quite adequately speak this or that foreign language. With respect to speaking a foreign language, a quite poignant truth is that sufficiently many individuals are a bit self-deceived in thinking that they can do so. In the case of the French language, it happens often enough that a foreigner is under the delusion that she/he can speak French simply because the person can, indeed, say a few words in French such as "Good-by" or "Thank you". 
CC Commons Attribution 4.0 License BY DOI: 10.19080/GJAA.2018.07.55572
Your next submission with Juniper Publishers will reach you the below assets

- Quality Editorial service

- Swift Peer Review

- Reprints availability

- E-prints Service

- Manuscript Podcast for convenient understanding

- Global attainment for your research

- Manuscript accessibility in different formats ( Pdf, E-pub, Full Text, Audio)

- Unceasing customer service

Track the below URL for one-step submission https://juniperpublishers.com/online-submission.php 